\title{
Labyrinthe
}

15 | 2003

Territoires : questions d'images

\section{Cultiver le paysage}

Hélène Soulier-Piotrowski

\section{(2) OpenEdition}

\section{Journals}

Édition électronique

URL : http://journals.openedition.org/labyrinthe/473

DOI : $10.4000 /$ labyrinthe.473

ISSN : 1950-6031

Éditeur

Hermann

Édition imprimée

Date de publication : 1 juin 2003

Pagination : 49-68

Référence électronique

Hélène Soulier-Piotrowski, « Cultiver le paysage », Labyrinthe [En ligne], 15 | 2003, mis en ligne le 24 mars 2005, consulté le 19 avril 2019. URL : http://journals.openedition.org/labyrinthe/473 ; DOI $10.4000 /$ labyrinthe.473

Ce document a été généré automatiquement le 19 avril 2019

Propriété intellectuelle 


\section{Cultiver le paysage}

Hélène Soulier-Piotrowski 